\title{
Jiwār: from a Right of Neighbourliness to a Right to Neighbourhood for Refugees
}

\author{
Tahir Zaman
}

Traditions as on-going "arguments extended through time" (MacIntyre 1988) allow us to move beyond the meta-narrative of the nation-state and find much needed space to begin thinking differently. The understanding that these arguments are on-going means they remain unresolved and open-the future is not the past repeated. We now live in a world wherein mobility stratifies and is a material mark of difference between people. For displaced people standing at the threshold of a sedentarist world created by the nation-state, religious traditions provide a powerful vernacular and idiom that allows them "to create a past" for themselves which will legitimate them in a way where just being themselves in the present will not allow them to do (Shils 1971: 133).

For Talal Asad $(1986,14)$, readings of what constitutes Islamic tradition and practice must be understood on its own terms. It cannot be disentangled or disembodied from the living practices of historically and socially located communities and their institutions - it is a discursive tradition wherein "each successive generation [of Muslims] confronts its particular problems via an engagement with a set of on-going arguments" (Haj 2009, 6). In conversation with David Scott, Asad tells us:

A tradition is in part concerned with the way limits are constructed in response to problems encountered and conceptualized. There's always a tension between this construction of limits and the forces that push the tradition onto new terrain, where parts or all of the tradition ceases to make sense and so needs a new beginning. And looked at another way: with each new beginning, there is the possibility of a new (or "revived") tradition. A new story about the past and future, new virtues to be developed, new projects to be addressed. (Asad cited in Scott 2006, 289-9o) 
Thinking of ways in which traditions are susceptible to re-calibration and re-assemblage rather than simply a continuity of well-rehearsed beliefs and practices holds open the distinct possibility of traditions to transform and move in new directions. A brief survey of refugee populations across the world today reveals that mass displacement crises are perhaps this generation's immediate "particular problem." More than half (53\%) of the 14.4 million refugees registered with the UNHCR came from three countries: Syria, Afghanistan and Somalia (UNHCR 2014, 9). This number excludes the 5.1 million Palestinians who are displaced and receive assistance from UNRWA. Similarly, Muslimmajority countries account for four of the top five countries that are hosting refugees (ibid.). ${ }^{1}$

The response to this movement of displaced people has been characterised by ambivalence, ambiguity, and even paradox on the part of majority Muslim states. It is in this encounter between settled resident populations and the arrival of the newly displaced who are often co-religionists, that a "sedentarist metaphysics" (Malkki 1992, 31) positing the nation-state as the moral container for people, culture, and politics is called into question. Here, the dissonance of contemporary Islamist approaches to the Muslim other is laid bare for all to see. In what follows, I draw on the Turkish state response to on-going Syrian displacement and the Syrian state's response to the earlier displacement of Iraqis $\left(2005^{-11}\right)$ to illustrate how the sedentarist logic of the nation-state impedes practices of conviviality that emerge from the lived realities of encounter between those already resident and those who newly arrive.

In the case of the Turkish response to the Syrian displacement crisis, the AKP cleaves to the exclusionary logic of the nation-state. On the one hand, Islamic rhetoric is mobilised to express solidarity with the displaced. In May 2013, following a car-bombing in the Hatay province bordering Syria, Prime Minister Recep Tayyip Erdoğan openly mobilised religious symbolism in reference to displaced Syrians: "My siblings in Reyhanlı should serve as anșār to the muhäjirūn who fled from the brutality of al-Assad. They should fulfil the same duty, they should also open their homes exactly like it happened at the time [of the Prophet]" (Hurriyet Daily News, May 24, 2013). On the other hand, displaced

1 The numbers should be taken as a conservative estimate as they do not include refugees who have spontaneously self-settled in urban locations and have not availed themselves of the protection and assistance available under the aegis of the UNHCR. 
Syrians are readily configured as an available pool of exploitable labour. Access to the labour market in Turkey reveals the contradictory positions taken by the Turkish state towards Syrian refugees in its clumsy attempts to reconcile an ethical position (its religious narrative of hospitality) with a political position (state interests). Such dissonance has led some commentators to characterise the AKP as following policies of urban neoliberalism with Islamic traits (Karaman 2013). Two years after the bombing in Hatay, the Minister of Work and Social Security, Faruk Çelik, was taking a less generous stance in relation to Syrians right to work, stating: "It would be unfair to take away their [local Turkish] jobs and give them to refugees" (Reuters, o7 August 2015). By January 2016, there was another volte-face as the AKP government announced it would be opening up access to the labour market for Syrian refugees following an agreement with the European Union wherein Turkey agreed to stem the movement of migrants out of Turkey in exchange for $\$ 3.3$ billion and favourable European entry visa requirements for Turkish citizens (Reuters, 11 January 2016).

The unprecedented numbers of Syrian, Iraqi and Afghan asylum-seekers transiting through Turkey and across the Aegean since the summer of 2015 indicates that the Turkish state has hitherto been reticent in responding to the protection needs of self-settled urban refugees. This has been partially addressed through Article 91 of the 2014 Foreigners and International Protection Law that makes specific reference to the idea of temporary protection recognizing the collective character of displacement crises. Invoking temporary protection measures to deal with the mass influx of refugees into Turkey has meant theoretically, for Syrians at least, more straightforward access to secondary rights pertaining to education, healthcare, and the labour market.

The temporal nature of such protection should be considered in light of the fact that where refugees are directly administered by the Turkish state they are in camps located close to the Syrian border-emphasising that the primary concern for the Turkish authorities is on managing displaced people rather than protecting them. Temporary protection provides a bulwark against full local integration of the displaced and encourages repatriation to Syria. Following outbreaks of anti-Syrian sentiment and violence in cities with a large Syrian population in August 2014, the Turkish state predictably reverted to doing what states faced with a large foreign displaced populations often do-encampment. The response also draws attention to the conflicting narrative of a universal hospitality anchored in the ethics of religious responsibility and the imposition of conditionalities on hospitality by the Turkish state, which privileges first and foremost a territorialized understanding of rights sanctioned by the nation-state. The Mayor of Gaziantep from the AKP, Fatma Şahin, declared: 
People took refuge in our city to protect their lives and their families after the civil war in Syria. It wasn't their choice but an existential necessity. They took refuge with their neighbours they saw as a safe port. Being neighbours is a sacred relationship according to our beliefs. We are making massive efforts to enable them to live on their own land in peace. We want our Syrian brethren to have a place where they can live in Syria. [Emphasis added] (Kutahyali 2014).

Such statements underscore the degree to which religious ideas are subordinate to the "national order of things" (Malkki 1995) whereby the practicable solution to a mass-displacement crisis is the common-sense approach of having the refugees return home where they supposedly belong. The ambiguities and contradictions of temporary protection expose the arbitrary character of the decision-making process on the part of local authorities as they struggle with the tension between conditional and unconditional hospitality. The emphasis on neighbourliness as being a "sacred relationship" should not go unremarked upon. As we have seen, the AKPs treatment of neighbourliness is characterised by ambiguity and ambivalence. It is mobilised at both local and national scales - the Syrian refugee as a physical neighbour and Syria as a neighbouring country. In what follows, I will outline an Islamic discourse of neighbourliness and its practice. Jiwār, interpreted not only as a right and obligation to protect the stranger, but also as a social pattern of cohabitation, equips people with tools to negotiate and manage conflict in their own interests unencumbered by the spatial ordering and management projects of the state. It allows for the self to be constituted through relationships and opens up space for a nurturing and care of relationships between residents and new arrivals alike. The argument here is that proximity through everyday interaction renders the racial, ethnic, and linguistic particularities that construct the citizen, as "unremarkable" (Gilroy 2004, 40).

In the Islamic imaginary the loss of social and material capabilities through being made an exile is a fate worse than penury-it speaks of a poverty of relationships (Rosenthal 1997) or what has been described in refugee studies as "social disarticulation" (Cernea 1996). This we find encapsulated in Arabic loan words that have found their way into proximate languages. For instance, the word for a person living in poverty in Urdu is the same as that for the stranger in Arabic_-gharib. Similarly, a popular proverb in Damascus warns of the fate 
that lies in store for one forced to leave his home: yalli byitla' min dāru 'all miqdāruh - the one who leaves his home, lessens his value.

Nonetheless, the stranger cuts an ambivalent figure in Islamic tradition; standing in for a wide array of characters from students, traders, ascetic dervishes, pilgrims and forced migrants. While exile for the stranger may be accompanied by poverty, the response towards the stranger from those who are "in place" is often welcoming. Ahlan wa-sahlan-an oft-heard expression in the Arabic speaking world is more than simply a welcoming phrase. As alGhazāil (Sherif 1975, 83) observes it is the sound of awkwardness and barriers being removed: a welcome that finds "room in the heart and in the place." Literally, it is an invitation for someone to be at ease as if they were at home with their family. The word sahl, it should be noted, is also in reference to fertile plains to be contrasted with the inhospitable terrain of the desert dominating the landscape of the Arabian Peninsula. Good treatment of strangers was thus a highly regarded custom of pre-Islamic Arabian culture such that those who demonstrated kindness and generosity to strangers were lauded with the title of ma'wā al-gharib — refuge of the stranger (Rosenthal 1997, 68). This favourable disposition towards the stranger was further institutionalized by Qur'anic and Prophetic injunctions, which encouraged generosity and good conduct toward strangers.

In particular, the bolstering of the pre-Islamic tribal practice of jiwär-the granting of protection and assistance to the one seeking refuge, illustrates the central importance of hospitality toward the stranger. While jiwa a r was largely granted for a limited period it was not uncommon for the one granting, the mujir, to extend the scope of protection and assistance such that the one claiming protection, the mustajir , would be integrated fully into the fold of the clan of the mujir (Shoukri 2011, 5) - drawing attention to the fluid understandings of both belonging and kinship. The mujir , both before and after the advent of Islam, could grant protection and assistance to the mustajir, and the clan to which the mujir belonged was obligated to respect this decision without hindrance. The granting of jiwa ar carried much resonance in the Arab world in which Islam emerged. In providing jiwār, the guarantor and the clan he belonged to accumulated symbolic capital which raised the prestige and honour of the clan (ibid., 4-7). However, alliances between clans also pre-empted the possibility of jiwār. This understanding of jiwār as protection can be contrasted with a more contemporary reading of protection wherein the nation-state alone has monopolised the right to grant asylum.

An examination of the biography of the Prophet Muhammad reveals that jiwa ar was fundamental in securing the prophetic mission before the hijra-the collective migration of the nascent Muslim community from Makkah to 
Madina. The granting of jiwār to the Prophet by al-Muț'im ibn 'Adiy and its recognition as legitimate by the Quraysh following the Prophet's return from al-Tầif is an indication of the importance that Arab society attached to the custom of jiwār. The political gravity of the context in which al-Mut im granted protection and assistance to the Prophet cannot be understated given that the Prophet's overtures to the notables of al-Tâaif was deemed tantamount to sedition by the Quraysh leadership (ibid., 25-26).

It is following the hijra we begin to see a codified Islamic position on the concept of jiwār to develop beyond that of protection and assistance but also as a code of conduct governing social patterns of cohabitation. The significance of the Prophet's hijra lay not only in the act itself as a spiritual journey of self-renewal and religious re-birth but perhaps just as important was its material and social implications - the response it engendered. Securing sustainable livelihoods for displaced people was equally a concern at the time of the Prophet as it is today. The muhäjirūn (The name given to the forced migrants from Makkah) who had sought refuge in Madina found themselves at an economic and social disadvantage, having been forced to abandon much of their wealth in Makkah. Previously they had been accustomed to earning their livelihood through commerce. In Madina, they had to re-adjust to the demands and mainstays of the local economy — craft and agriculture. Many had left their friends and families behind in Makkah and felt alienated in their new surroundings. How did this community of believers respond to the challenges of hosting a displaced population? The response of the anșār (Literally, the supporters: this is the name given to the people of Madina who pledged allegiance to the Prophet Muhammad and gave refuge to the exiled Muslims from Makkah) has been celebrated in the Qur'an and held forth as an example for future generations (Qur'an, 59:9). Despite the apparent generosity of the anșār, it was deemed necessary to legislate for a system guaranteeing the muhäjirūn a means to earn a living and make a contribution to society. In contemporary parlance, a durable solution facilitating local integration was founded. Within the first year of the hijra, the Prophet established a contract of brotherhood: the $m u$ 'a $k h \bar{a}$, between 45 men of the muhäjirūn and an equal number from the anșār promoting mutual support between the pairings in matters of material assistance, care, advice, and even extending to inheritance rights (though this latter provision was later to be abrogated).

Here, hospitality is not immutable but transformational. To use Derrida's (2000) felicitous phrase, the mastery of the house is ceded in order to transform both host and guest into something different—into neighbours or kin. The concept of jiwa a r should thus be correctly recognised as a right of neighbourliness - one recognised as both a "moral and legal right" ('Abd al-Rahim 
20o8, 19) underpinned by the Qur'an and the example of the Prophet. Generally speaking, a neighbour was considered to be anyone (Muslim or otherwise) residing within a radius of forty houses in any direction. Indeed, the Prophet explained that one's neighbour has rights whether they are Muslim or not. He said:

The rights of a neighbour are that, if he falls sick you visit him, if he dies you follow his funeral procession, if he asks you for a loan you lend to him, if he is in need you assist him, if good befalls him you congratulate him, if misfortune befalls him you console him, that you not build your house up above his, blocking out the breeze, and that you not afflict him with the aroma of your cooking pot without offering him some. ${ }^{2}$

In his discussion on the duties owed to the neighbour recorded in The Revival of the Religious Sciences, al-Ghazālì recalls the oft-cited tradition in which the Prophet emphasized the rights of the neighbour to the extent that his companions were left with the distinct impression that the Prophet may commend the neighbour to be included as a rightful heir to an inheritance (alGhazālī 2005, 675).

What value then does an Islamic reading of neighbourliness hold for us in contemporary times? How are such rights of neighbourliness for the newly arrived to be balanced against the rights of more long-standing neighbours? Today, there is little doubt that the production of locality and relational ties therein are so heavily shaped by the collective efforts of the apparatus of the nation-state whose citizenry is pitted against a referent migrant other. However, this simple binary occludes how the nation-state operates concomitantly with the interests of capital. Those who possess adequate levels and compositions of capital are arguably looked favourably upon by agents of the nationstate. In the context of Western Europe, for instance, anti-immigration raids or border profiling practices are rarely carried out on white middle class males who may have overstayed beyond the terms stipulated on their visa. Yet, localities with longstanding histories of migration from Africa and Asia, whose residents include citizens and non-citizens alike, are the target of state policies that seek to produce a "hostile environment" for migrants and the communities they reside in (Jones et al., 2017).

2 Although the authenticity of this hadith is contested by some scholars, it is important to acknowledge that understanding of the rights and obligations that underpin neighbourly relations are broadly recognised as part of a discursive tradition (al-Zabīdī 1994, 6: 308-309). 
Thus, we can see that beyond neighbours being recognised as citizens by the nation-state there are also those who occupy a range of differentiated legal statuses contingent on their migration histories: there are those who enjoy a right to residence granted through having educational or labour mobility; some who may have been granted a temporary protection status; and yet others who enjoy no recognised status-effectively illegalized. Such statuses do not necessarily correlate with duration of stay but may nonetheless shape the production of neighbourly relations. Illegalized migrants, for instance, may find it difficult to access and navigate certain spaces of the city wherein they are made visible to agents of the nation-state. Yet, the presence of people with differentiated legal statuses living cheek by jowl to produce localities and alternative socialities offers an opportunity to move beyond sedentarist assumptions underpinning the distribution and allocation of resources through the nation-state. This emphasis on propinquity and presence as the seat from where rights are located opens possibilities for the stranger to become familiar. This allows us to understand the practice of jiwär not only in terms of protection, as discussed above, but also more broadly in terms of conviviality.

It is instructive to think about neighbourhoods as both centrifugal and centripetal flows rather than territorially bounded. In her seminal sketch of her local high street in Kilburn, Doreen Massey (1991, 28) observes that "what gives a place its specificity is not some long internalised history, but the fact that it is constructed out of a particular constellation of social relations, meeting and weaving at a particular locus." This quality of "throwntogetherness" (Massey 2005) is at the heart of what characterises a neighbourhood. The bodies carrying social relations themselves are arriving from other places at different times on journeys that may not yet be complete. The neighbourhoods in which they arrive can thus be thought of as "the contemporaneous existence of a plurality of trajectories; a simultaneity of stories-so-far" (ibid.: 12). Here, the openended possibility of everyday mundane social interactions that take place in parochial spaces generates an ethos that invites the stranger. Empathy towards the other emerges as a by-product of this "situated multiplicity" mediated by the coming together of bodies, matter, and technology (Amin 2008: 19).

This explicit acknowledgement and accommodation of difference lies at the heart of conviviality as an integral aspect of civic formation in public space-however fleeting and momentary (Amin 20o8). Conviviality—let us 
be clear-requires work and maintenance. This work, however, cannot be derived from unequal hierarchical relationships. It is work that demands everyday practices of support, reciprocity, and narratives of friendship. Conviviality is not to be located in a premeditated collaboration that seeks to endorse a cosmopolitanism from above (think of state instigated policies of multiculturalism), but rather it is about being affected by the condition of the world to create a "cartography of togetherness" (Rolnik cited in Nowicka \& Vertovec 2014,347 ). The openness of possible encounter borne out of this "throwntogetherness" and the ethical response it engenders cultivates a culture of neighbourliness. This ethical impulse is at one and at the same time a learned and an instinctive response to a given situation. In paying attention to one's relationships, virtues are disciplined and care of the self is practised (Zigon $2014,21)$. That is not to say this relational ethic is always positive-as we all know tension and conflict between neighbours is commonplace. The point being emphasised here is there is an explicit acknowledgement of the other; an encounter negotiated between the one who is present and the one who arrives. This encounter does not happen outside of the sedentarist logic championed by the nation-state. In fact, this encounter witnesses the collision of two very different geographical imaginaries-producing ambivalence or even dissonance.

Through a broadly consistent refusal to grant refugees the right to work, governments ensure that the responsibility to provide welfare for refugees falls squarely on the shoulders of international organizations. Refugees come to regard local integration as a dim prospect; buttressing the logic of the host state, which opposes integration in favour of creating a more vulnerable refugee population that is able to induce greater financial resources from the international community to share the cost of hosting refugees. It also marks the refugees as recipients of aid that the local population is not entitled to. Entitlements bestowed through the auspices of the state were a point of contention between marginalized communities on the peripheries of Baghdad. The bureaucratic labelling of Palestinians as "guests" by the state was adopted in public discourse in Iraq. A popular Arabic proverb has it that the stranger should be wellmannered-Ya gharīb kun adīb! Likewise, Palestinians in Iraq were expected to know their place and show gratitude for the hospitality shown to them rather than challenge the stratification that placed them below the status of citizen. Fatima, a 40-year-old housewife from Mosul, told me:

Whenever there would be a problem between us and our neighbours or someone, they'd remind us we are Palestinians living in Iraq. They'd say things like Inta nazil wa dabchu 'ala saṭ̂ [you're a guest and you dance on 
my roof]. It's an old Iraqi proverb that means you think you're better than us; that you don't even have respect for your hosts.

Top-down interventions to manage populations by the state in this way do little to nurture practices of neighbourliness. Negotiating the encounter with difference is done so from a distance produced by the nation-state that exacerbates feelings of suspicion and mistrust. Shared histories and collective memories of earlier migrations remain, however. In the camps of Southern Damascus kinship ties already existed not only with Palestinian Iraqis that had fled Iraq in the earlier phase of the crisis but with relatives that had settled in Damascus following the nakba of 1948. Here is Fatima again. This time relating her experience of being a refugee in Syria:

Dealings with Palestinian Syrians are good. They've supported us and I don't feel like a foreigner around them. This is a Muslim Arab country, so I don't have the sense of ghurba [exile and alienation]. It's only that my wider family is far from me that I feel like that I'm away from home. There are so many similarities here and with our lives in Iraq; food, language [...] yes, there are some differences but it's not great. I feel like that we're all Palestinians together here.

Fatima immediately associates the largely positive interactions she has with Palestinian Syrians with not feeling foreign. Linking the two is the fact that she is in a Muslim Arab country and as such has an understanding of how social relations are structured and mediated. However, one cannot ignore that she refers exclusively to Palestinian Syrians rather than Syrian society at large. As with Syrian refugees in Athens, access to the city was limited. Palestinian Syrians in Damascus were largely concentrated in Mukhayyim al-Yarmūk.

For others forcibly displaced from Iraq, the sense of ghurba was more tangible. This is particularly the case for men who are expected to be breadwinners in their households. The liminal space that refugees occupy; the ambivalent position of the state toward Iraqi refugees generally, designating them as guests and the issuing of fixed term residency status of 2-3 months, adds to this sense of ghurba. This feeling of alienation may not initially stem from relations with the host population but rather the bureaucracy of state and surrogate state (Slaughter \& Crisp 2008) that marks them as other, which in turn creates a distinction for the host population. Here Abū Yasīn recognizes the effect this has on refugee and host community relations, narrating fears of an uncertain future: 
It affects [you] even at the level of the people, and not the State. People get to know that this house is not a Syrian or Palestinian Syrian house. So, social interaction isn't entirely harmonious. Some people like Iraqis; I mean I get on well with my neighbours. But, how do they deal with you? You're not an ibn al-balad [... ] Up 'til now, I consider myself a guest, a visitor here temporarily and then leaving. I don't have any expectation of permanent residence. ${ }^{3}$

The use of the expression ibn al-balad is telling. Literally meaning "son of the land," the term belongs to a category of terms used to highlight autochthony and difference between those who belong and those who fall outside the community. The term ibn al-balad fell into popular usage around the nineteenth century at a time in which local populations were coming to terms with the challenges of first having Turco-Circassian and then European colonialists occupying the same social and geographical space (El-Messiri 1978). In contemporary usage the term refers to someone who is legitimately entitled to the resources and welfare of the state and denotes belonging. Rights and citizenship are the bedrock on which the edifice of integration rests. For Abū Yasin, it is the nation-state that produces the anxiety, creating a sense of alienation. There is also ambivalence in the language that the state employs with respect to Iraqi refugees. At one and the same time, they are shaqiq (full brothers) and $\operatorname{duy} \bar{u}$ (guests), which points to a more temporal stay. Oscillating between the two categories refugees and host communities struggle to balance unconditional hospitality - as a shaqiq the refugee is transformed into ibn albalad. Yet, the interventions of the Syrian state and humanitarian agencies transform the refugee into a guest constrained by the limits of hospitality. By affirming only negative rights and deflecting the burden of welfare responsibility onto international humanitarian organizations, the Syrian government in tandem with the UNHCR and UNRWA established a parallel system of welfare protection that in fact marks refugees as others. This is contrary to the UNHCR's own guidelines on refugee protection in urban areas, which aims to "reinforce existing fully authorized delivery systems, whether they are public, private or community based" (UNHCR 2009a).

3 Author's interview. Damascus, 18 November 2010. 
The right of neighbourliness, which at various times the Prophet granted or was granted, emphasises relational understandings of rights. They are less rights residing in individuals, but rather rights possessed by the Other who seeks recognition (Soroush 2000, 62). Al-Ghazālī notes that there are four kinds of neighbour; each with a corresponding set of rights. The non-Muslim neighbour who has the claim of neighbourliness rights over you; the Muslim neighbour who has the additional claim of Islamic brotherhood; the non-Muslim relative, who is also a neighbour, has both the right of neighbourliness and the rights due from kinship. Finally, the Muslim neighbour who is also kin enjoys all three claims of rights (Sherif 1975, 100). Everyday encounters are littered with reference to real or imagined kin relationships. Fictive kin relationships continue to be a prominent feature of propriety in the Arab and wider Muslim world. Suad Joseph $(1996,200)$ observes that through the idiom of fictive relationships expectations of a set of moral or ethical practices is re-called in dealings with the stranger to produce a "learned grammar of sociability" (Buonfino and Mulgan 2009, 16). This we find in everyday colloquialisms that are liberally sprinkled in languages spoken by Muslims—kolay gelsin!yi'țik al'äfiyih! khasté nabāshì! for whenever we find someone having done a kindness or worked on our behalf.

The cartography of togetherness delineated by the nation-state recognises only those already resident as citizens or those whom the nation-state has admitted onto its territory. The production of spatialities that this cartography seeks to map cannot simply be reduced to those already resident. We must recognise that for those the nation state seeks to make invisible, for whom a clear legal relation to the nation state has not been established, an alternative sociality is constantly being cultivated - a mobile commons that privileges socio-cultural relations rather than a legal relation. It is in this world that various categories of people on the move exist. In spite of their uncertain legal statuses, people on the move inhabit and construct along with resident others a "world of knowledge, of information, of tricks for survival, of mutual care, of social relations, of services exchange, of solidarity and [a] sociability that can be shared" (Hardt \& Negri 2011, 190). In the following sections, we will consider how "cartographies of togetherness" are imagined, inscribed, and interpreted through an Islamic ethic of neighbourliness. Here I draw on observations from a number of research sites: Calais, Athens, Damascus, and Urfa.

The so-called "Jungle" in Calais meets the criteria for what Isin and Rygiel (2007) describe as "abject space." Despite refugee life being "rendered invisible and inaudible" by the state, spaces like the "Jungle" become sites for politics 
rather than spaces of abjection. This subtle difference they argue suspends the logic of the nation-state and in so doing makes acts of resistance possible (ibid., 184-5). A practical ethic has produced what Africa, a long term-resident calls "a wonderful place" where he not only has neighbours but has "made six thousand persons [sic] my brothers." (Afrika et al. 2017). This, he says makes him "a rich man" adding "and because of that I sleep in safety" (ibid.). This practical ethic is founded in reciprocal relations where "respect with a little smile $[\ldots]$ can solve everything here in the Jungle-everything. Because they [refugees] are looking for respect" (ibid.). The main avenue of the Calais "Jungle" was lined with Afghan and Eritrean restaurants. The proprietors of the restaurants, themselves refugees and migrants, did not simply organise the space of their establishments for the purpose of dining. They recognised the needs of their fellow travellers and permitted residents of the camp to stay at the restaurant, socialise with other residents, share information about possible routes out of Calais, and charge their mobile phones. Warmth, conversation, and cups of tea were at close hand for the residents of the camp biding their time in these eateries. Here, we find a contemporary mu'äkhā among residents, contrasted with life outside of the "Jungle" in the cities of France where interaction is often hostile-particularly with police.

To overcome the diminution of social and material capabilities, human activity is re-interpreted through a solidaristic narrative of religion. Being a refugee is de-stigmatized and moves beyond the totalizing discourse of humanitarian and refugee law; mapping an alternative cognitive space in which she is located (Bauman 1993, 148). Thus, while social space may be constructed through a knowledge of propinquity, the learned grammar of sociability or a cultural capital embodied as an Islamic habitus permits refugees to read exile in Muslim majority countries as familiar and as home. 'Ārif, an Iraqi refugee I met in Damascus in 2010, told me:

For Iraqis to leave Iraq it was hard. No one wanted to leave Iraq; they needed a safe place to go. I found my belief in Islam makes it easier for me to think about being a refugee. It's a hard thing to do, to leave your home, but I know that my Prophet did the same, and he was a refugee. If we think about it, in Islam we see that borders are not important. There are no nationalities. The differences are with language. All the land belongs to God and you can find a place to live and work wherever you go.

An Islamic narrative allows refugees to re-imagine their migration. As 'Ārif reminds us: "all the land belongs to God," i.e. territorial sovereignty belongs to God rather than the state. Everyone has the right to move freely without 
hindrance-borders have no place under this schema. The Islamic narrative demands that the stranger is entitled to "find a place to live and work wherever [she goes].'

Here we must also acknowledge that urban contexts are increasingly central to the spontaneous self-settlement of refugees as they seek out secure places to live and work (Pantuliano et al. 2012). Exploring hospitality extended to forced migrants in the case of Greece, Katerina Rozakou (2012) contrasts the outsider perspective of the state, INGOS, and international agencies administering to the needs of asylum-seekers with that of a more culturally grounded approach located in relations of solidarity between activists and migrants in the city. On the streets of Athens, Rozakou (ibid., 574) observes, forced migrants are "attributed the power and agency that they typically lack in other aid contexts [...reversing] established hierarchies between the citizen and the noncitizen, the indigenous and the stranger." However, hierarchical relations linger which privilege "profoundly cultural" understandings of what it means to be host and guest (ibid.). This then is the contradictory tension ever present in host-guest relations. As Derrida $(2000,14)$ reminds us: "Hospitality can only take place beyond hospitality, only by deciding to make it come from beyond, by surmounting hospitality which paralyzes itself on the threshold where it is" (emphasis added).

The so-called "European refugee crisis" which saw over a million people journey across the Eastern Mediterranean into Europe from 2015 onwards has helped produce new socialities that attempt to move beyond hospitality and towards neighborliness. In the city of Athens, migrants, refugees and some local residents worked together to create and maintain autonomous housing collectives or squats to welcome those who had been made immobile by the European Union. In the absence of support from the formal humanitarian architecture and the state, refugee residents of squats drew on collective and personal memories of both the village and the $h \bar{a} r a$ - the urban neighbourhood street wherein understandings of conviviality, mutual aid, and neighbourliness are integral to longstanding socio-cultural traditions. This vernacular of solidarity resonated and was made intelligible to local Greek activists who themselves had extrapolated practices of mutual aid found in the village in response to the crisis of austerity imposed by the Greek state and the European Union-underscoring a "recontextualisation of village-hood" to locate horizons of solidarity in the city (Rakopoulos 2016, 143).

This remains a partial horizon. Accommodation for self-settled refugees is limited to very few neighbourhoods from 59 municipalities of the city. While these neighbourhoods are conveniently located in the city centre and border onto other neighbourhoods densely populated by migrants, it would be a 
stretch to suggest that the recently arrived refugees are connected to the city. One resident of the Acharnon School squat told me, "the squat is great, we live like a real community here. My family is here. My friends are here. It's like a small village." When I asked whether there was much interaction with the neighbours he replied, "there's nothing to do, we don't really know anyone out there. We spend most of our time smoking argileh in here."

A shared sociability is clearly circumscribed here. The degree to which encounter and interaction is possible for the residents of the squats is thus heavily contingent on the networks of volunteers and activists choosing to visit and contribute their time and resources at the squats. This can be attributed in part to a lack of connectivity with the economic life of the neighbourhoods where the squats are located. While the squats were arguably conceived as an iteration of the mobile commons, their relational sense of place remains hemmed in rather than being centrifugal and allocentric. Opportunities for residents to reach out to other neighbours are limited and constrained to the physical space of the squat where activists and volunteers arrive to help meet the evident and urgent needs of residents.

Notions of karam or hospitality and generosity remain integral to Arab and wider Islamic culture (Chatty 2014). In everyday relations forced migrants in the urban context of the Middle East are able to maintain dignity or karāma as they negotiate their experience of exile-hospitality accounts for little if there is no dignity. ${ }^{4}$ While the prestige of the host is enhanced through acts of generosity (Chatty 2014, 36; Shoukri 2011, 10), the refugee is able to retain a dignity through everyday neighbourly interactions, which is often made inaccessible through a securitized humanitarian gaze. A religious narrative on conviviality takes us beyond hospitality by transforming the guest into a neighbour.

Refugee-led community development responses are integral to opening up spaces for everyday neighbourly interactions. These home-like spaces emphasise relational aspects of home (Taylor 2015) where protection and security is found within ties of fictive and actual kinship rather than with international NGOS and agencies. They are not only spaces in which material resources are accessed but familiar welcoming places wherein refugees are recognised as being more than just a case number - they are friends or part of a larger family. They are quotidian everyday spaces, rather than spaces that are explicitly labelled as religious, in which the potential to facilitate and maintain

4 A commonly cited tradition of the Prophet states that among those who will not be exonerated on the Day of Judgement is he who reminds recipients of his charity to them. See also the Noble Qur'an 2:264. 
relationships with both guest and host communities is nurtured. They are convivial "spaces where recognition as well as contestation and conflict can take place" (Dikeç 2002, 244). Iraqi, Palestinian, and Syrian refugees I have worked alongside over the past six years have all established self-help initiatives rhizomatically connected to transnational networks of self-reliance. (Examples include Beit ISP and al-Rābita al-Falastiny fĩ al-Irāq in Damascus [Zaman 2016], and ad-Dar in Istanbul: <http://www.addarcenter.org/>) From the security of these home-like spaces opportunities emerge for the refugee to be both host and neighbour. A Syrian participant in the city of Urfa in Turkey echoed exilic experiences of Iraqi and Palestinian refugees I had met in Damascus; signalling the salience of neighbourly visits as a barometer of meaningful relationships:

I like it when they (Turks) treat us equally and not as "poor" refugees. When they visit and invite us to their homes-I feel normal and equal to them. I'm not made to feel like a refugee. It's great when people call on you like this. Visiting people's homes like this means we have proper relations.

\section{Conclusion: the Right to Neighbourhood}

The recovery and foregrounding of the concept and practice of $j i w \bar{a} r$ invites us to reconsider the distribution of rights and entitlements. It calls for an interrogation of where the ummah is located and challenges us to think beyond the constraints of methodological nationalism. The discursive move towards relations of neighbourliness complicates binaries of citizen and non-citizen. The concomitant shift away from notions of deserving and undeserving brings less audible voices into the discussion. It asks us to reconsider rights and obligations in light of those who are present.

Echoing the growing literature in critical urban geography on the "right to the city" (Lefebvre 1967, Purcell 2003, Harvey 2003, Marcuse 2010), the right to neighbourhood puts forward the case of enfranchising inhabitants of cities rather than simply national citizens, a right of neighbourliness serves to protect the wellbeing, dignity and integrity of all those resident (temporarily or otherwise) in a neighbourhood, including those who arrive as strangers. It protects the neighbourhood against the caprice of a neoliberal nation-state that serves to defend the interests of those close to its centre. The right to neighbourhood upholds not only social, cultural and political rights but economic 
rights also. Lefebvre $(1967,158)$ provocatively labelled the right to the city "a cry and a demand" and it has been a clarion call for the left since. Peter Marcuse writes "the demand is of those who are excluded, the cry is of those who are alienated; the demand is for the material necessities of life, the aspiration is for a broader right to what is necessary beyond the material to lead a satisfying life" (Marcuse 2009,19o). At a time where there is an increased enclosure of public space in the city, there is heightened anxiety around the growing trend for those who are excluded, alienated, and dispossessed to be corralled into "abject spaces [...] where their existence is rendered invisible and inaudible" (Isin and Rygiel 2007, 184).

The politics of propinquity (Amin 2004, 38) I am advocating here is far from parochial. It does not serve to exclude those on the margins. Rather, social distance between self and Other are compressed and boundaries are recognised as spaces to cross rather than bound. It understands an individual, a neighbourhood, or a city to be part of a greater whole. Relationships are configured radially. It is useful here to think of a concentric circle spiralling outwards, or of a matryoshka doll—the spaces in between are not void but thick with meaningful relationships producing "multiple geographies of affiliation, linkage and flow" (ibid.).

The cultural geographer, Thomas Tweed $(2006,97)$ asserts that those who ascribe to a religious worldview are guided by "autocentric" and "allocentric" reference frames. The former can be equated with a concern for the care of the self, whereas the latter refers to concern with that which is external to oneself. These reference frames enable those who ascribe to religious beliefs and practices to orient themselves temporally and spatially by placing their bodies within homes, homelands, and the cosmos. For those cultivating a virtue ethic modelled on the Prophet Muhammad, geographies of affiliation flow outwards beyond any circumscribed boundaries of the nation-state. In encountering the stranger as a neighbour, virtues as learned, habituated dispositions take on transcendent meanings that brings the believer closer to the love of God, as the Muslim ethicists would have it. Thus, simultaneously providing both an autocentric and allocentric reference frame.

\section{Bibliography}

'Abd al-Rahim, M. 2008. "Asylum: a moral and legal right in Islam." Refugee Survey Quarterly 27(2): 15-23.

Afrika et al. 2017. Voices from the Jungle: Stories from the Calais Refugee Camp. London: Pluto Press. 
Amin, A. 2004. "Regions Unbound: Towards a New Politics of Place." Geografiska Annaler B 86: 33-44.

Amin, A. 2008. "Collective culture and urban public space." City 12(1): $5^{-24}$.

Asad, T. 1986. The Idea of an Anthropology of Islam. Centre for Contemporary Arab Studies. Occasional Paper, Washington, DC: Centre for Contemporary Arab Studies. Buonfino, A. and G. Mulgan. 20og. Civility Lost and Found. London: Young Foundation.

Cernea, M. 1996. "Understanding and preventing impoverishment from displacement: reflections on the state of knowledge." In Understanding Impoverishment: the Consequences of Development Induced Displacement, edited by Christopher McDowell. Oxford: Berghahn.

Chatty, D. 2014. "Iraqi refugees in the Arab Muslim world: Ottoman legacies and Orientalist presumptions." In Managing Muslim Mobilities: between Spiritual Geographies and the Global Security Regime, edited by A.H. Fàbos and R. Isotalo, New York: Palgrave Macmillan, 21-38.

Derrida, J. 2000. "Hospitality." ANGELAKI. Journal of the Theoretical Humanities 5(3): 3-18.

Dikeç, M. 2002. "Pera Peras Poros Longings for Spaces of Hospitality." Theory, Culture and Society 19(1-2): 227-247.

Al-Ghazālī, Abū Hāmid. 2005. Ihyyā’ 'Ulūm al-Dīn. Beirut: Dār ibn Hazm.

Gilroy, P. 2004. "Multiculture in times of war: an inaugural lecture given at the London School of Economics." Critical Quarterly 48(4): 27-45.

Haj, S. 20o9. Reconfiguring Islamic Tradition: Reform, Rationality, and Modernity. Stanford, CA: Stanford University Press.

Hürriyet Daily News. "Turkish PM calls on Reyhanlı locals to resist 'provocations." Hürriyet Daily News, May 24, 2013. Available online at: <http://www.hurriyetdaily news.com/turkish-pm-calls-on-reyhanli-locals-to-resistprovocations.aspx?pageID $=238 \& \mathrm{nID}=475^{26} \&$ NewsCatID $=341>$.

Isin, E.F. \& K. Rygiel. 2007. "Abject spaces: frontiers, zones, and camps." In Logics of Biopower and the War on Terror, edited by C. Masters \& E. Dauphinee. Basingstoke: Palgrave Macmillan, 181-203.

Jones, H., Gunaratnam, Y., Bhattacharyya, G., Davies, W., Dhaliwal, S., Forkert, K., Jackson, E. and Saltus, R. (2017). Go Home?The Politics of Immigration Controversies. Manchester: Manchester University Press.

Joseph, S. 1996. "Gender and family in the Arab world." In Arab Women: between Defiance and Restraint, edited by S. Sabbagh. New York: Olive Branch Press, 194-202.

Kagan, M. 2011. "We live in a country of the UNHCR': The UN surrogate state and refugee policy in the Middle East." Research Paper No. 201, UNHCR New Issues in Refugee Research. Geneva: Policy Development and Evaluation Service UNHCR. 
Karaman, O. 2013. "Urban neoliberalism with Islamic characteristics." Urban Studies $5 \mathrm{O}(16): 3412-3427$.

Kutahyali, R.O. 2014. "Syrian refugees under attack in Turkey," Al-Monitor, August 14, 2014. Available online at: <http://www.al-monitor.com/pulse/originals/2014/o8/ kutahyali-syrian-refugees-under-attack-turkey-gaziantep.html $>$.

Lefebvre, H. 1996/1967. “The Right to the City." In Writings on Cities, edited by E. Kofman and E. Lebas. London: Blackwell, 63-184.

MacIntyre, A. 1988. Whose Justice? Which Rationality? Notre Dame, IN: Notre Dame University Press.

Malkki, L.H. 1992. "National geographic: the rooting of peoples and the territorialisation of national identity amongst scholars and refugees." Cultural Anthropology 7(1): $22-44$.

Malkki, L.H. 1995. "Refugees and exile: from "refugee studies" to the national order of things." Annual Review of Anthropology 24: 495-523.

Marcuse, P. 20og. "From critical urban theory to the right to the city." City: Analysis of Urban Trends, Culture, Theory, Policy, Action, 13(2-3): 185-197. doi: 10.1080/13604810 902982177 .

Massey, D. 1991. "A global sense of place." Marxism Today 35(6): 24-29.

Massey, D. 2005. For space. Sage Publications: Thousand Oaks, CA.

El-Messiri, S. 1978. Ibn al-balad: a concept of Egyptian identity. Leiden: E.J. Brill.

Nowicka, M. \& S. Vervotec. 2014. "Comparing convivialities: Dreams and realities of living-with-difference." European Journal of Cultural Studies 17(4): 341-356.

Pantuliano, S., V. Metcalfe, S. Haysom, and E. Davey. 2012. "Urban vulnerability and displacement: a review of current issues." Disasters 36(S1): S1-S22, doi: 10.1111/ j.1467-7717.2012.01282.x.

Rakopoulos, T. 2016. "Solidarity: The Egalitarian Tensions of a Bridge-Concept." Social Anthropology 24(2): 142-151.

Reuters. "Turkey will not give Syrian refugees right to work-labour minister." Reuters, o7 August 2015. Available online at: <http://uk.reuters.com/article/uk-turkey-syriarefugees-workers-idUKKCNoQC1UH20150807>. Accessed 3o March 2016.

Reuters. "Turkey plans to introduce work permits for Syrian refugees, minister says." Available online at: <http://uk.reuters.com/article/us-europe-migrants-turkeyidUKKCNoUPoQP2016o111>. Accessed 3o March 2016.

Rosenthal, F. 1997. “The stranger in medieval Islam.” Arabica 44(1): 35-75.

Rozakou, K. 2012. "The biopolitics of hospitality in Greece: humanitarianism and the management of refugees." American Ethnologist 39(3): 562-577.

Scott, D. 2006. "The Trouble of Thinking: an Interview with Talal Asad." In Powers of the Secular Modern:TalalAsad and his Interlocutors, edited by D. Scott and C. Hirschkind. Stanford, CA: Stanford University Press, 243-303.

Sherif, M.A. 1975. Ghazali's Theory of Virtue. Albany: State University of New York Press. 
Shils, E. 1971. "Tradition." Comparative Studies in Society and History 13(2): 122-159.

Shoukri, A.M. 2011. Refugee Status in Islam: Concepts of Protection in Islamic Tradition and International law. London: I.B. Tauris.

Slaughter, A. and J. Crisp. 2008. "A surrogate state? The role of UNHCR in protracted refugee situations." In Protracted refugee situations, edited by G. Loescher, J. Milner, E. Newman and G. Troeller. Tokyo: United Nations University Press, 123-140.

Soroush, A. 2000. "The sense and essence of secularism." In Reason, Freedom and Democracy in Islam: Essential Writings of 'Abdolkarim Soroush. New York: Oxford University Press, 54-68.

Taylor, H. 2015. Refugees and the Meaning of Home: Cypriot Narratives of Loss, Longing and Daily Life in London. Basingstoke: Palgrave Macmillan.

Turton, D. 2005. "The Meaning of Place in a World of Movement: Lessons from Longterm Field Research in Southern Ethiopia." Journal of Refugee Studies 18(3): $258-28$ o.

Tweed, T.A. 2006. Crossing and Dwelling: a Theory of Religion. Cambridge, MA: Harvard University Press.

UNHCR. 2014. Statistical Yearbook 2014. Geneva: UNHCR.

UNHCR. 2009. UNHCR Policy on Refugee Protection and Solutions in Urban Areas. Geneva: UNHCR.

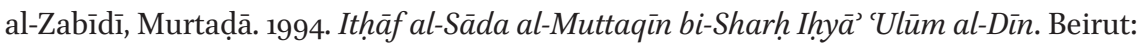
Mu’assasat al-Tārīkh al-'Arabī.

Zaman, T. 2016. Islamic Traditions of Refuge in the Crises of Iraq and Syria. New York: Palgrave Macmillan.

Zigon, J. 2014. "Attunement and fidelity: two ontological conditions for morally beingin-the-world." Ethos 42: 16-3o. 